J. Product. \& Dev., 24(1): 15 - 35(2019)

\title{
APPLICATION OF HACCP SYSTEM, BASED ON ISO 22000:2005 METHODOLOGY FOR PRODUCING STRAWBERRY CONCENTRATES
}

\author{
Mahmoud M. Awad M. Soliman; A. El-Makhzangy" \\ 1. Department of Food and dairy Science and Technology, Faculty of \\ Technology \& Development, Zagazig University, Egypt. \\ *All Corresponding address to attiamakhzangy@yahoo.com
}

\section{ABSTRACT}

This work aims to present a methodology to carry out hazard and control measures assessments to properly establish operational prerequisite programmes (oPRPs) and the HACCP plan in the Strawberry concentrates industry according to the ISO 22000 standard, this study focused on the manufacture of Strawberry concentrated, which sold as raw materials to juice filling factories.

In this study, the presence of (sterilization, Packing \& Firm closure), were identified as critical control points. (CCP) and presence of (Pesticide residues at the receiving stage, Magnetic trap) were identified as Operational Pre-Requisite Program Points. after the implementation of HACCP. This was due to stricter controls in terms of GMPs, GLPs, GHPs and CCPs.

Total bacteria count, Yeast \& Mold counts were $2.08,2.48$ $\left({ }^{l o g}\left(\mathrm{fu} / \mathrm{cm}^{2}\right)\right.$; respectively but E-Coli, Salmonella sp. Hepatitis A Virus The results were negative. The heavy metals detected were Fe, $\mathrm{Zn}$, and $\mathrm{Mn}$ were positive results and values were reduced by thermal treatment. As, $\mathrm{P} b, \mathrm{~cd}, \mathrm{Hg}$ the results were negative and the results were in accordance with CODEX STAN 193-1995, Pesticides residues were detected and the results were in accordance with CODEX STAN 193-1995.The values were reduced by thermal treatment and storage, The water used in the production process has been analyzed physically, chemically and microbiologically; although it is used only for washing fruit. 
Generally, the study emphasized that the required disciplined approach is best provided by the ISO 22000 procedure applied as an integral element of total quality management principles, which include (HACCP, GMP, GHP, GLP and document control (e.g., ISO 9001 Quality Systems). ISO 22000 FSMS embracing

Conclusively, implementation of the ISO 22000 standard in the fruit concentrates industry guarantees food safety and helps improve their competitiveness in the global market.

Kay words: Food Safety, Quality, ISO 22000, (HACCP), Fruit, Strawberry Concentrates

\section{INTRODUCTION}

There are several public health concerns, with which we have to deal on daily basis. In this regard, Soman \& Raman . (2016) think that food safety is considered as one of the most prominent major public health concerns. Thus, it is a real challenge to provide food supplies that are safe and conforming;

Therefore, in order to face the fast growing and increasingly complicated sets of the global food chain, we shall analyze, evaluate and manage these risks thoroughly. Thus, food safety can be ensured through the adoption of the basic principles of food hygiene across the food chain in consistence with the Hazard Analysis and Critical Control Point System. In this sense, a new procedure was introduced for hazard analysis and risk assessment, in accordance with the ISO 22000:2005 methodology.

In addition, according to (CAC, 1997), Food Safety refers the guarantee that food will not cause any harms to the consumer, when it is prepared and/or consumed. Hence, food safety can be defined as the level of security that we attain by ensuring food hygiene.

Botanically, all fruits are similar plant organs, fruits vary widely in their shape, size, color, texture, flavor, nutritional properties, potential for extended shelf-life and ability to withstand different types of processing. In spite of being delicious, nutritious and desirable components of our diet, fruits suffer from being extremely perishable. Therefore, it is always 
preferred to preserve them for longer shelf-life, and to provide easier transport to any locations distant to the site of production.

Simply strawberry is a widely grown hybrid species of the genus Fragaria, collectively known as the strawberries. The fruit is widely appreciated for its characteristic aroma, bright red color, juicy texture, and sweetness. It is consumed in large quantities, either fresh or in such prepared foods as preserves, juice, pies, ice creams, milkshakes, and chocolates (Wikipedia, 2018).

Therefore, the aim of this study application of HACCP system, based on ISO 22000:2005 methodology for producing strawberry concentrates.

\section{MATERIALS AND METHODS}

\section{MATERIALS}

Strawberry Fruits Festival variety was obtained from the market of fruit and vegetables in New Damietta, Damietta, Egypt, during season 2016.

\section{METHOD OF MANUFACTURE}

\section{Manufacture of Strawberry Concentrate}

Fruit Concentrate processing includes several steps (receive of raw materials, First Washing, Sorting, Final Washing, Crushing /extraction, Preheating, Filtration, Concentration pasteurization, Filling and Storage. Processing steps can be summarized in Figure (1).

\section{Application of ISO 22000}

ISO 22000- 2005 specifies the requirements for a food safety management system that combines the following generally recognized key elements to ensure food safety along the food chain, up to the point of final consumption:

— interactive communication;

- system management;

- prerequisite programmes;

- HACCP principles. 


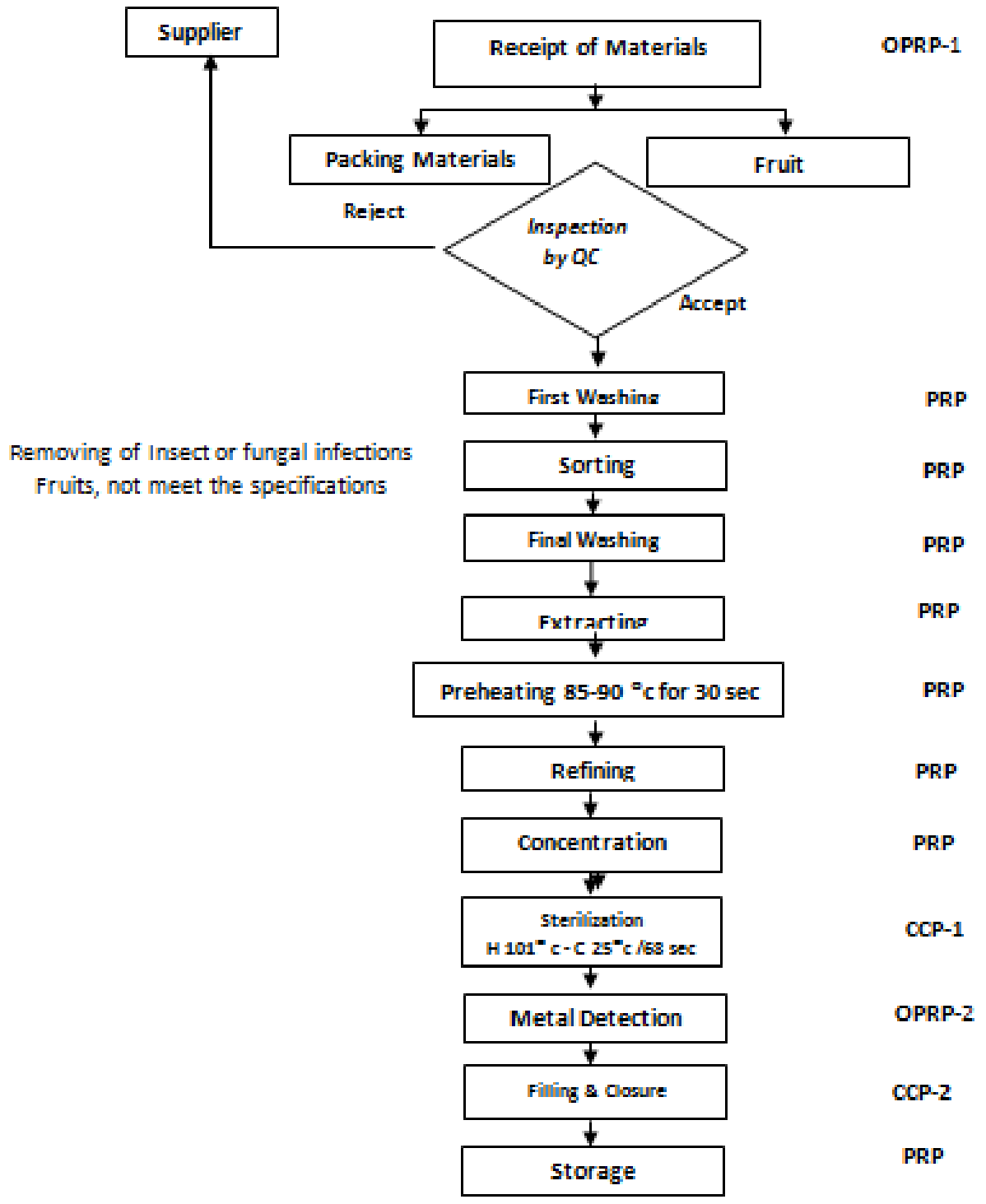

Figure (1). Flow Diagram for the manufacture of Strawberry Concentrate 
According to Sikora, and Nowicki (2007). ISO 22000 standard the organizations should plan and improve all processes that are needed to realize safe products through effective improvements, planned actions implementing and monitoring as well as keeping going the control measures connected to food safety. This standard came into force on September 1, 2005 is constructed of 8 chapters: (1) Scope, (2) Normative references, (3) Terms and definitions, (4) Food safety management system, (5) Management responsibility, (6) Resource management, (7) Planning and realization of safe products, and (8) Validation, verification and improvement of the food safety management system. Figure (2) describes the implementation order of food safety systems Sikora and Nowicki (2007).

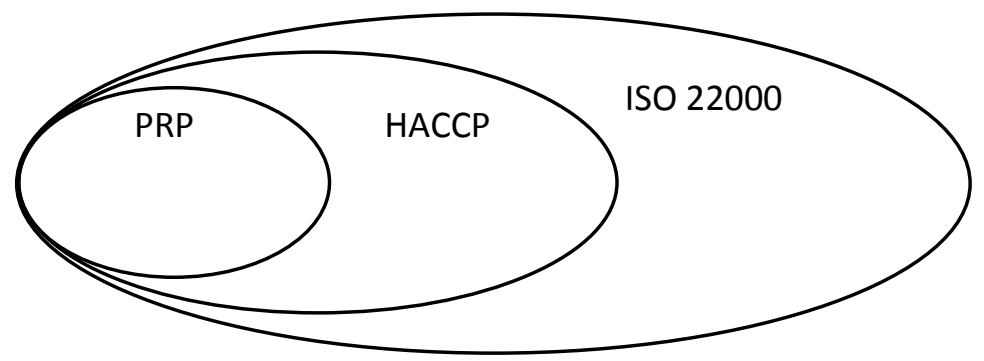

Figure (2): Description of the Implementation Order of Food Safety system

The PRPs are based on good manufacturing practices or good hygienic practices, Food safety experts have found that well-functioning PRPs simplify and strengthen the HACCP plan, in general Prerequisite programs (PRPs) provide the foundation for hazard analysis and critical control point (HACCP) to function. According to Scoti, and Stevenson, (2006) PRP include Facilities, including construction and layout of buildings, training and competencies, Personal hygiene, waste and sewage disposal, air, water and energy control, Cleaning and sanitizing, Preventive maintenance, Calibration, Prevention of cross contamination, Pest control, Glass and hard plastic control, Chemical control, Environmental monitoring, Product traceability and recall, Complaint investigation and Labeling. 


\section{Application of HACCP system}

Application of HACCP system: Hazard analysis and critical control points (HACCP) consisted of observing food preparation to identify sources and modes of contamination, Processing line of manufacturing of Fruit concentrated based in the following seven principles: 1 . Conduct a hazard analyses, 2 . Identify the critical control points (CCPs), 3, Establish critical limits for preventive measures associated with each identified CCP, 4. Establish CCP monitoring requirements, 5. Establish corrective actions to be taken when monitoring indicates then a deviation from an established critical limit, 6. Establish verification procedures and 7. Establish record-keeping and documentation procedures. CCPs were determined according to the decision tree.

Figure (3), as described by Horchner et al. (2006), according to Lokunarangodage, et al (2016) The mandatory procedures in ISO 22000:2005 management elements are handled through food safety, that consists, (1). Control of records (2). Control of documents (3). Corrections (4). Corrective Actions (5). Potentially Unsafe products (6). Withdrawals (7). Internal Audits.

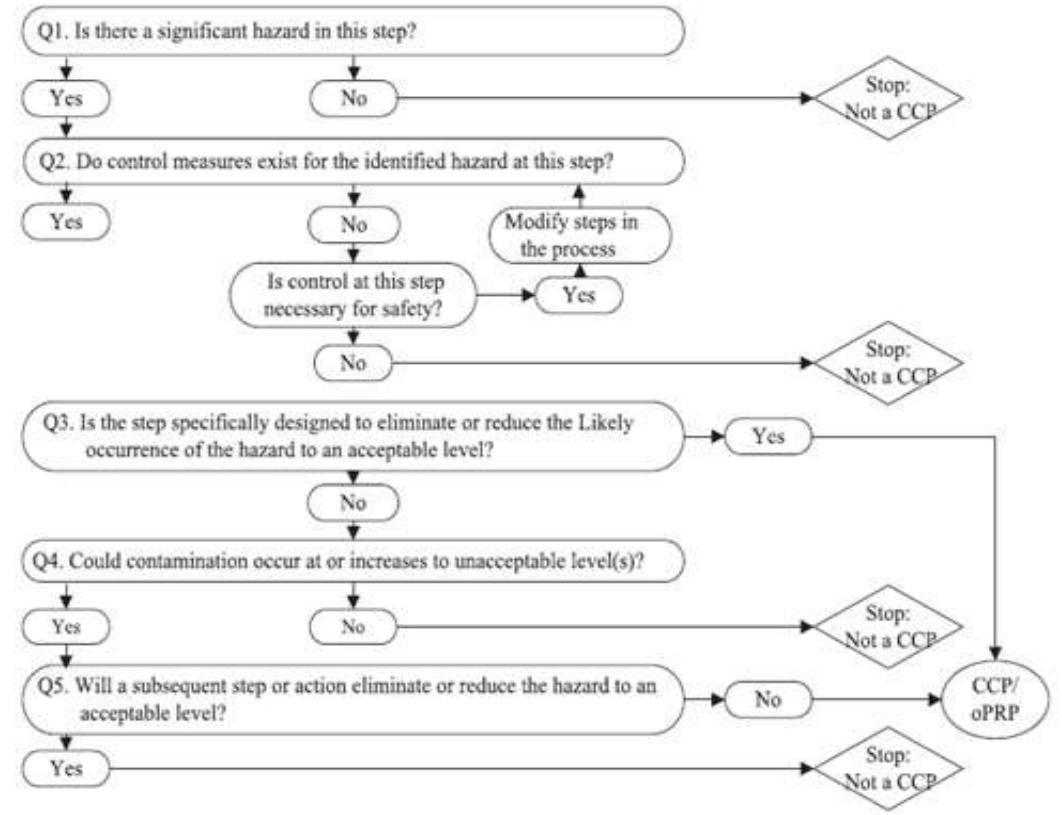

Figure.(3): Decision tree for HACCP implementation adopted from Horchner et al. (2006). 


\section{METHODS OF ANALYSIS}

\section{Chemical and Physical analysis}

\subsection{Total Soluble Solid (Brix):}

Ph value and Titratable Acidity (TTA) were determined according to AOAC (2012) The measurement was carried out in the chemical laboratory at Misr Italy Co.-New Damietta , Damietta Government.

\subsection{Color}

Color was determined in Strawberry Concentrates according to Gomez et al (1998), measurements Color Tester LS2000 (Hunter Associates Laboratory, Reston, VA, USA).

\subsection{Bostwick}

Bostwick was determined in Strawberry Concentrates according to MARSH et al. (1980).

\subsection{Heavy Metals}

Heavy Metals was determined in Strawberry concentrates according to the method of ISO:8288(1986) by inductively coupled plasma optical emission spectrometry after high pressure microwave digestion, The measurement was carried out in Central Lab for soil, food and feed, Faculty of Technology and Development - Zagazig University, Certified laboratory in accordance with international standards of quality "ISO 17025".

\subsection{Pesticide Residues}

Pesticide Residues was determined in Strawberry Concentrates as Recommended by QuEChERS Method Quick and Easy Method (QuECHERS) the Standard Method EN 15662:2008 Cieślik, et al (2011) The measurement was carried out in Central Lab of Residue Analysis of Pesticides and Heavy Metals in Food (QCAP Lab) Dokki, Giza Government, The Lab hold ISO 17025 Certificate.

\subsection{Aflatoxins (Patulin)}

Aflatoxins was determined in Strawberry Concentrate according to Liquid chromatography quantitative determination of Patulin in clear apple juice AOAC(2002), 49.7.03 according to Maragos, et al 2015, The measurement was carried out in Central Lab of Residue Analysis of Pesticides 
MAHMOUD AWAD et al.

and Heavy Metals in Food (QCAP Lab) Dokki, Giza Government, The Lab hold ISO 17025 Certificate.

\subsection{Vitamin $C$}

Vitamin C was determined in Strawberry Concentrate according to ElIshaq, and Obirinakem, (2015). The measurement was carried out in Food Analysis Laboratory, Agricultural Research Center, Dokki, Giza Government, and EOS Lab.

\section{Microbiological examination}

\subsection{Total bacterial counts (TBC)}

Total bacterial counts TBC was determined according to ISO 4833, (2003) using plate count agar media.

\subsection{Yeasts and molds count (Y\&M)}

The counts of yeast \& molds were determined according to the method described by ISO 21527-1,2 (2008) using plate counts agar media.

\subsection{Coliform counts}

Coliform bacterial counts was carried out according to the method of ISO 4832, (2006) using MacConkey agar media.

\subsection{Detection of Escherichia coli.}

Detection of E. coli was carried out according to the method of Leong et al. (1985). E. coli detection was carried out on duplicate plates of Violet Red Bile Lactose agar (V.R.B.G).

All microbiological analyzes was carried out in the Microbiological laboratory at Misr Italy Co.- New Damietta ,Damietta Government.

\subsection{Determination Hepatitis A virus}

Determination Hepatitis A virus according to Mäde, et al (2013) International Methods for Microbiological food and water analysis ISO-TS 15216_2/2013, The measurement was carried out in the Microbiological laboratory at Misr Italy Co.- New Damietta, Damietta Government.

\section{Sensory Evaluation}

The sensory qualities evaluated were: Color, Flavor, Taste and Overall acceptability. The Strawberry Concentrated juice blends together with a reference sample (packaged in glass bottle). The sensory analysis was 
carried out using twenty-member of well-trained. Each sensory attribute was on a 9 - point Hedonic Scale with $1=$ disliked extremely while $9=$ liked extremely as reported by Iwe (2010).

\section{Statistical Analysis.}

Statistical Analysis was performed using the SPSS and MS Excel procedure, Duncan's multiple comparison procedure was use to compare the means. A probability of $\mathrm{P} \leq 0.05$ was used to establish statistical significance.

\section{RESULTS AND DISCUSSIONS}

\section{Physical and Chemical Analysis of Strawberry Concentrate.}

This part of study was planned to through some lights on quality and safety of Strawberry concentrate by three types of sample according to storage period; zero time, 6 months and 12 months, the chemical and physical analysis presented in Table (1).

The Color of the strawberry Pulp samples was characterized objectively. The $\mathrm{L}^{*}, \mathrm{a}^{*}$ and $\mathrm{b}^{*}$ values of a pasteurized non-stored strawberry Pulp were 23.89, 25.26 and 9.36, respectively. a/b value 2.72 . after concentrate the results were as follows a, L, b and a/b 31.24, 26.94 ,12.20 and 2.21, (at Zero time), Kalbasi and cismeros (2007)

Vitamin C.: High temperature has effects on vitamin C content, strawberry pulp were 84 reach to 148 for Strawberry Concentrates (at zero time) and decreased after storage 6 months and 12 months to 125, 115, respectively.

Heavy Metals: The concentrations of heavy metals in strawberry pulp, Fe, $\mathrm{Zn}$ and $\mathrm{Mn}$, was 3.1, 0.85 and 2.12; respectively but $\mathrm{As}, \mathrm{Cd}, \mathrm{Hg}$ and $\mathrm{Pb}$, were negative. Strawberry concentrated Fe, Zn and Mn, was 4.79, 1.15 and 3.3; respectively, after storage for 6 months and 12 months the value of Fe decreased after concentration with continued decrease $25 \%, 9 \%$ and $20 \%$ of the initial value; respectively. While $\mathrm{Zn}$ decreased by 5\%, 9\% and 24\%; respectively and Mn decreased by $22 \%, 16 \%$ and $22 \% \%$; respectively. 
Table (1). Physical and Chemical Analysis of Strawberry Concentrate.

\begin{tabular}{|c|c|c|c|c|}
\hline \multirow[t]{2}{*}{ Items } & \multicolumn{4}{|c|}{ Storage time (Month) } \\
\hline & Pulp & 0 Time & $6 \mathrm{M}$ & $12 \mathrm{M}$ \\
\hline \multicolumn{5}{|l|}{ Chemical Analysis } \\
\hline Brix & $8.00^{b}$ & $16.60^{\mathrm{a}}$ & $16.63^{\mathrm{a}}$ & $16.65^{\mathrm{a}}$ \\
\hline $\mathrm{ph}$ & $3.84^{\mathrm{c}}$ & $3.74^{\mathrm{a}}$ & $3.72^{\mathrm{a}}$ & $3.68^{\mathrm{a}}$ \\
\hline ACIDITY & $0.84^{\mathrm{c}}$ & $1.72^{\mathrm{b}}$ & $1.75^{\mathrm{b}}$ & $1.84^{\mathrm{a}}$ \\
\hline POSTWICK (cm/30sec.) & $14.50^{\mathrm{a}}$ & $11.50^{\mathrm{b}}$ & $11.50^{\mathrm{b}}$ & $11.80^{\mathrm{b}}$ \\
\hline BLACK SPECS & None & None & None & None \\
\hline Vitamin C & $84^{\mathrm{d}}$ & $148^{\mathrm{a}}$ & $125^{\mathrm{b}}$ & $115^{\mathrm{c}}$ \\
\hline \multicolumn{5}{|l|}{ Color } \\
\hline L (lightness) & $23.88^{\mathrm{c}}$ & $31.24^{\mathrm{b}}$ & $34.12^{\mathrm{a}}$ & $35.49^{\mathrm{a}}$ \\
\hline a (redness) & $25.26^{\mathrm{a}}$ & $26.94^{\mathrm{a}}$ & $25.45^{\mathrm{a}}$ & $25.11^{\mathrm{a}}$ \\
\hline B (yellowness) & $09.36^{\mathrm{d}}$ & $12.23^{\mathrm{c}}$ & $14.88^{\mathrm{b}}$ & $15.90^{\mathrm{a}}$ \\
\hline $\mathrm{a} / \mathrm{b}$ & $02.71^{\mathrm{a}}$ & $02.21^{\mathrm{b}}$ & $01.70^{c}$ & $01.57^{\mathrm{d}}$ \\
\hline \multicolumn{5}{|l|}{ Heavy Metals } \\
\hline Iron $\mathrm{Fe}$ & $3.10^{c}$ & $4.79^{\mathrm{a}}$ & $3.60^{b}$ & $2.88^{\mathrm{c}}$ \\
\hline Zink Zn & $0.85^{\mathrm{c}}$ & $1.15^{\mathrm{a}}$ & $1.05^{\mathrm{b}}$ & $0.80^{\mathrm{c}}$ \\
\hline Manganese Mn & $2.12^{\mathrm{c}}$ & $3.30^{\mathrm{a}}$ & $2.80^{\mathrm{b}}$ & $2.20^{\mathrm{c}}$ \\
\hline Arsenic As & $\mathrm{ND}$ & ND & ND & ND \\
\hline Lead $\mathrm{Pb}$ & ND & ND & ND & ND \\
\hline Cadmium c d & ND & ND & ND & ND \\
\hline Mercury Hg & $\mathrm{ND}$ & $\mathrm{ND}$ & $\mathrm{ND}$ & $\mathrm{ND}$ \\
\hline \multicolumn{5}{|l|}{ Pesticide Residues } \\
\hline Iprodione & $0.01^{\mathrm{a}}$ & ND & ND & ND \\
\hline Malathion & $0.02^{\mathrm{a}}$ & ND & ND & ND \\
\hline Omethoate & ND & ND & $\mathrm{ND}$ & $\mathrm{ND}$ \\
\hline Dimethoate & $0.16^{\mathrm{a}}$ & ND & ND & ND \\
\hline ND: not detected & & & & \\
\hline
\end{tabular}

Pesticide residues: Different processing operations like washing, peeling, frying, freezing and cooking of fruits and vegetables can be effectively applied on fruits and vegetables to minimize the risk of pesticides on human health, cooking under open conditions resulted in 85 to 98 percent losses by volatilization. Cooking under closed conditions resulted in hydrolysis with 50 percent of the chlorothalonil being recovered unchanged on the crop 
Ahmed, et al (2011) .this observation are in agreement with that reported by Szpyrka, et al (2015), Bakrc, et al (2014). The concentrations of pesticides residues found in Strawberry concentrated samples analyzed were lower than the respective EU established MRLs, thus complying with the European legislation and Pesticide residues in food: toxicological evaluations. WHO, FAO (2017).

\section{Microbiological examination of Strawberry concentrate}

From Table (2) shown results of microbiological analysis of Strawberry Pulp for Total bacteria count, Yeast \& Mold counts were 2.08, $2.48 \mathrm{cfu} / \mathrm{cm}^{2}$; respectively while E-Coli, Salmonella sp. Hepatitis A Virus and Aflatoxin were not detected both in pulp and concentrates during the storage period.

Table (2). Microbiological examination of Strawberry concentrate

\begin{tabular}{|c|c|c|c|c|}
\hline \multirow{3}{*}{ Microbiological Analysis } & \multicolumn{4}{|c|}{ Microbiological counts $\left(\log \mathrm{cfu} / \mathrm{cm}^{2}\right)$} \\
\hline & \multirow{2}{*}{ Pulp } & \multicolumn{3}{|c|}{ Concentrate } \\
\hline & & 0 & $6 \mathrm{M}$ & $12 \mathrm{M}$ \\
\hline TBC & $2.08^{\mathrm{a}}$ & ND & ND & ND \\
\hline Y\&M & $2.48^{\mathrm{a}}$ & ND & ND & ND \\
\hline E-Coli & ND & ND & ND & ND \\
\hline Salmonella sp. & ND & ND & ND & ND \\
\hline Hepatitis A Virus & ND & ND & ND & ND \\
\hline Aflatoxin (Patulin) & ND & ND & ND & ND \\
\hline
\end{tabular}

T.B.C : total bacterial counts, Y\&M: yeast and mold counts, ND: not detected,

*: Average of three samples

\section{Sensory evaluation of Strawberry concentrate}

The sensory quality attributes of reconstituted Strawberry concentrated samples are stated in Table (3).

\section{Application of ISO 22000 for manufacturing of Strawberry concentrate}

The implementation of food safety system (ISO 22000) is a continuous process based on the management concepts of an iterative fourstep management methods; the PDCA cycle (plan, Do, Check and Act). 
Table (3). Sensory quality attributes of Strawberry concentrate

\begin{tabular}{|c|c|c|c|c|c|}
\hline \multirow[b]{2}{*}{ Items } & \multicolumn{5}{|c|}{ Quality attributes } \\
\hline & Taste & Color & Flavor & Textures & $\begin{array}{c}\text { Over all } \\
\text { acceptability } \\
\%\end{array}$ \\
\hline $12 \mathrm{M}$ & $6.00^{\mathrm{c}}$ & $6.55^{\mathrm{c}}$ & $5.10^{\mathrm{c}}$ & $6.50^{\mathrm{d}}$ & 60.00 \\
\hline $6 \mathrm{M}$ & $7.25^{\mathrm{b}}$ & $7.50^{\mathrm{ab}}$ & $7.10^{\mathrm{b}}$ & $7.00^{\mathrm{cd}}$ & 71.75 \\
\hline 0 time & $8.50^{\mathrm{a}}$ & $7.10^{\mathrm{b}}$ & $8.35^{\mathrm{a}}$ & $7.00^{\mathrm{cd}}$ & 81.50 \\
\hline Pulp & $9.00^{\mathrm{a}}$ & $8.00^{\mathrm{a}}$ & $8.00^{\mathrm{a}}$ & $9.05^{\mathrm{a}}$ & 85.00 \\
\hline $\mathbf{X 1}$ & $9.00 \mathrm{a}$ & $8.00^{\mathrm{a}}$ & $8.05^{\mathrm{a}}$ & $7.45^{\mathrm{dc}}$ & 81.25 \\
\hline $\mathbf{X} 2$ & $7.50^{\mathrm{b}}$ & $7.50^{\mathrm{ab}}$ & $7.1 \mathrm{~b}$ & $8.00^{\mathrm{b}}$ & 75.00 \\
\hline
\end{tabular}

\subsection{Listing the prerequisite programs (PRPs)}

The PRPs represent the conditions and/or the necessary basic activities to maintain a hygienic environment for the production, handling and the provision of safe finished products all along the food product process. daCruz, et al. (2006).

\subsection{Preliminary steps to enable hazard analysis}

\subsubsection{Food safety team .}

A multidisciplinary team, composed of nine people was created in the company to implement the requirements of the system. The members of this team were trained thoroughly on the HACCP system and ISO 22000: 2005 standard. These are food safety team leaders, Q.A manager, Hygienist, Production manager, Maintenance manager, Supply manager, Storage manager, Planning manager, Sales manager. The team was committed to the study, development, establishment and review of all problems concerning the safety and management of their products.

\subsubsection{Product characteristics and intended use .}

The food safety team preceded to a complete description of the foodstuffs, by identifying their composition, chemical, biological and physical characteristics, the undergone treatments, durability, storage conditions and distribution methods. The description concerns raw materials 
(fruits) and finished products (fruit concentrates). Table (4) summarizes the characteristics and intended use of fruit concentrates.

\subsection{Hazard identification and determination of acceptable levels.}

The food safety team established a list of hazards recorded in the hazard identification and Hazard analysis.

\subsection{Hazard assessment.}

The identified hazards were evaluated during the scheduled meetings by the food safety team. Hazard analysis is carried out at all stages of Strawberry concentrates production. During hazard analysis, hazards were categorized into four general areas: biological (pathogens), chemical (toxic substances), physical (external particles) and allergens hazards.

A hazard is considered significant if the score resulting from the multiplication of the probability $(\mathrm{P})$ by the severity $(\mathrm{S})$ values $\left(\mathrm{P}^{*} \mathrm{~S}\right)$ was above 4 Fernandez, et al (2014). A significant hazard is one of such a nature that their elimination or reduction to an acceptable level is essential to the production of safe foods ILSI, (1999).

\subsection{Selection and assessment of control measures (ISO 22000, section 7.4.4.)}

According to the hazard assessment results, control measures are selected with the help of the decision tree Figure (3). These measures are classified according to whether they should be managed through Operational Prerequisite Programs (oPRPs) or by the HACCP plan, using the following criteria Fernandez et al., (2014); ISO 22000, 2005, Section 7.4.4.):

\subsection{Establishing the operational prerequisite programs .}

According to (ISO 22000, Section 7.6.1.) For each critical control point and oPRP, an HACCP plan and oPRP plan are established respectively by specifying the food safety hazards to be controlled, control measures, critical limits (for the CCP) or action limits or action criteria (for the oPRP), monitoring procedures and actions to be taken if critical limits or actions limits or action criteria are exceeded. Tables (5) and (6) illustrate an oPRP plan model and the HACCP plan.

\subsection{Establishing the verification plan.}

The food safety team established a verification plan to check if the HACCP plan is functioning as envisaged, which specifies the purpose, the 
Table (4). Fruit Concentrates Description and intended use

\begin{tabular}{|c|c|}
\hline Product & $\begin{array}{l}\text { The product is the natural Strawberry } \\
\text { concentrated obtained from crushing and } \\
\text { refining of natural fruit and fully maturity, and } \\
\text { free of seeds without additives and pasteurized } \\
\text { at a temperature of not less than Heat } 101 \mathrm{c} \text { and } \\
\text { cooling } 25 \mathrm{c} \text { for } 68 \text { seconds }\end{array}$ \\
\hline Composition & Natural strawberries fruits full maturity \\
\hline Origin & vegetarian \\
\hline Packaging Size & Aseptic Bags in Drums $220 \mathrm{Kg}$ \\
\hline Shelf-life & 24 Month \\
\hline $\begin{array}{l}\text { Storage and transport } \\
\text { conditions }\end{array}$ & $\begin{array}{l}\text { stored at a temperature not exceeding } 25 \mathrm{c} \\
\text { In a dry, clean and well-ventilated place. }\end{array}$ \\
\hline $\begin{array}{l}\text { Labelling relating to } \\
\text { the food safety }\end{array}$ & $\begin{array}{l}\text { Name of product - barrel number - net weight - } \\
\text { date of production - expiry date - Brix. }\end{array}$ \\
\hline $\begin{array}{l}\text { Physical-chemical } \\
\text { characteristics }\end{array}$ & Brix, Ph, Color, Bostwick, Acidity \\
\hline $\begin{array}{l}\text { Microbiological } \\
\text { characteristics }\end{array}$ & $\begin{array}{l}\text { Free from Any Viable Spoilage or Pathogenic } \\
\text { Micro-Organisms }\end{array}$ \\
\hline \multirow[t]{2}{*}{ Use of the product } & $\begin{array}{l}\text { Intermediate product for the manufacture of } \\
\text { juices and jams }\end{array}$ \\
\hline & $\begin{array}{l}\text { The product is used after the addition of other } \\
\text { components (water - sugar - other additives by } \\
\text { product type) and according to the instructions } \\
\text { for the manufacture of juices and jams }\end{array}$ \\
\hline
\end{tabular}

methods, frequencies and responsibilities for the verification activities. Endproduct analyses (microbiological analyses) are made and compared with earlier established reference values. The verification plan model of the operational prerequisite programs and HACCP plan is represented in Table (5). 


\subsection{Establishing the documentation and record keeping .}

Various documentation models were used for monitoring selected measures control and ensuring appropriate corrective actions., documentation and records are established to provide evidence of effective implementation of the system Mortimore (2001).

\section{Conclusion}

This study sets out a methodology that is applied to a practical example to carry out hazard and control measures assessment in order to properly establish operational prerequisite programmes (oPRPs) and the HACCP plan based on ISO 22000:2005 Methodology.

In this study, the presence of (sterilization, Packing \& Firm closure), were identified as critical control points. and presence of (Pesticide residues at the receiving stage, Magnetic trap) were identified as Operational PreRequisite Program Points. after the implementation of HACCP. This was due to stricter controls in terms of GMPs, GLPs, GHPs and CCPs.

The results of microbiological analysis of Strawberry Concentrate showed that implementation of HACCP can improve the microbial quality of Fruit Concentrates. The heavy metals detected were Fe Zn, As, Mn, P, $\mathrm{C}, \mathrm{D}$, and $\mathrm{Hg}$ and the results were in accordance with CODEX STAN 1931995, Fe, Zn, and Mn were positive results and values were reduced by thermal storage treatment .As, $\mathrm{P} \mathrm{b}, \mathrm{c} \mathrm{d}, \mathrm{Hg}$ the results were negative ., Pesticides residues were detected and the results were in accordance with CODEX STAN 193-1995. The values were reduced by thermal treatment and storage, The water used in the production process has been analyzed physically, chemically and microbiologically, although it is used only for washing fruit.

\section{Acknowledgements}

The authors are very grateful to the company Misr Italy for collaborating in this study.

\section{REFRENCES}

Ahmed, A., Randhawa, M. A., Yusuf, M. J., \& Khalid, N. (2011). Effect of processing on pesticide residues in food crops: A review. J Agric Res, 49(3), 379-390. 
AOAC International. 2002. AOAC Official Method 2000.02 Patulin in clear and cloudy apple juices and apple puree. In: HorwitzW, editor. Official methods of analysis of AOAC International. 17 ed. Gaithersburg (MD): AOAC International; p. 49.7.03.

AOAC (2012). Official Methods of Analysis of the Association of Official Analytical Chemists, 20th ed.

Alimentarius, C. (1997). The Codex Alimentarius Commission and the FAO/WHO Food Standards Programme. Recommended International Code of Practice General Principles of Food Hygiene. CAC/RCP, 1-1969.

Bakrc, G. T., Acay, D. B. Y., Bakırcı, F., \& Ötleş, S. (2014). Pesticide residues in fruits and vegetables from the Aegean region, Turkey. Food chemistry, 160, 379-392.

Cieślik, E., Sadowska-Rociek, A., Ruiz, J. M. M., \& Surma-Zadora, M. (2011). Evaluation of QuEChERS method for the determination of organochlorine pesticide residues in selected groups of fruits. Food Chemistry, 125(2), 773-778.

Codex, S. T. A. N. (1995). STAN 193-1995. Codex General Standard for Contaminants and Toxins in Food and Feed, Codex Alimentarius Commission.

DaCruz, A. G., Cenci, S. A., \& Maia, M. C. (2006). Quality assurance requirements in produce processing. Trends in Food Science \& Technology, 17(8), 406-411.

El-Ishaq, A., \& Obirinakem, S. (2015). Effect of temperature and storage on vitamin $\mathrm{C}$ content in fruits juice. International journal of Chemical and Biomolecular science, 1(2), 17-21.

EN, B. S. (2008). 15662: 2008. Foods of plant origin-determination of pesticide residues using GC-MS and. or LC-MS/MS Following Acetonitrile Extraction/Partitioning and Clean-up by Dispersive SPE-QuEChERSMethod.[2012-07-12]. http://esearch. cen. eu/esearch.

Fernandez -Segovia, I., Pérez-Llácer, A., Peidro, B., \& Fuentes, A. (2014). Implementation of a food safety management system according to ISO 22000 in the food supplement industry: A case study. Food control, $43,28-34$. 
Gomez, R., Varon, R., Amo, M., Tardaguila, J., \& Pardo, J. E. (1998). Differences in the rate of coloration in tomato fruit. Journal of food quality, 21(4), 329-339.

Horchner, P. M., Brett, D., Gormley, B., Jenson, I., \& Pointon, A. M. (2006). HACCP-based approach to the derivation of an on-farm food safety program for the Australian red meat industry. Food control, 17(7), 497510.

ILSI, (1999). International Life Science Institute, Validation and verification of HACCP. Belgium: ILSI Europe..

ISO 21527-1, (2008). International Standards Organization Microbiology of food and animal feeding stuffs-Horizontal method for the enumeration of yeasts and moulds International Standards Organization, Geneva, Switzerland.

ISO 4832, (2006) International Standards Organization Microbiology of food and animal feeding stuff-Horizontal method for the enumeration of Coliforms colony-count technique,

ISO 4833,(2003) International Standards Organization, Geneva, Switzerland International Standards Organization. Microbiology of food and animal feeding stuff-Horizontal method for the enumeration of microorganism's colony-count technique at $30^{\circ} \mathrm{C}$.

ISO/TS 15216-2 (2013). International Organization for Standardization. Microbiology of food and animal feed-horizontal method for determination of hepatitis A virus and norovirus in food using real-time RT-PCR — part 2: Method for qualitative detection..

ISO 8288, 1986. Water quality: Determination of cobalt, nickel, copper,zinc, cadmium and lead - Flame atomic absorption spectrometric methods.

ISO. (2005). Technical Specification/ Food Safety Management SystemsGuidance on the 265 Application of ISO 22000:2005. (ISO/TS 22004). .(1st ed.). (2005-11-15): 1-20.

Iwe M.O (2010). Handbook of Sensory methods and analysis, 75-78. Enugu Nigeria Rejoint Communication Science Ltd.

Kalbasi, A., and Cisneros-Zevallos, L. (2007). Fractionation of monomeric and polymeric anthocyanins from concord grape (Vitis labrusca L.) juice by membrane ultrafiltration. Journal of agricultural and food chemistry, 55(17), 7036-7042. 
Mäde, D., Trübner, K., Neubert, E., Höhne, M., \& Johne, R. (2013). Detection and typing of norovirus from frozen strawberries involved in a large-scale gastroenteritis outbreak in Germany. Food and environmental virology, 5(3), 162-168.

MARSH, G.L., BUHLERT, J.E. and LEONARD, S.J. 1980. Effect of composition upon Bostwick consistency of tomato concentrate. J. Food Sci. 45, 703-706.

Maragos, C. M., Busman, M., Ma, L., \& Bobell, J. (2015). Quantification of patulin in fruit leathers by ultra-high-performance liquid chromatographyphotodiode array (UPLC-PDA). Food Additives \& Contaminants: Part A, 32(7), 1164-1174.

Mortimore, S. (2001). How to make HACCP really work in practice. Food Control, 12(4), 209-215.

Leong, J. M., Nunes-Düby, S., Lesser, C. F., Youderian, P., Susskind, M. M., \& Landy, A. (1985). The phi 80 and P22 attachment sites. Primary structure and interaction with Escherichia coli integration host factor. Journal of Biological Chemistry, 260(7), 4468-4477.

Lokunarangodage, C. V. K., Wickramasinghe, I., \& Ranaweera, K. K. D. S. (2016). Review of ISO 22000: 2005, Structural synchronization and ability to deliver food safety with suggestions for improvements.

Scoti, U. N., \& Stevenson, K. E. (2006). HACCP: A Systematic Approach to Food Safety, Food Products Association.

Sikora, T., \& Nowicki, P. (2007). Food safety assurance according to Codex Alimentarius and ISO 22000 Standard. Polish Journal of Food and Nutrition Sciences, 57(4C), 489-493.

Soman, R., \& Raman, M. (2016). HACCP system-hazard analysis and assessment, based on ISO 22000: 2005 methodology. Food Control, 69, 191-195.

Strawberry August 05 ,2018 available at https: //en. wikipedia. org/wiki/ Strawberry \#Nutrients.

Szpyrka, E., Kurdziel, A., Matyaszek, A., Podbielska, M., Rupar, J., \& Slowik-Borowiec, M. (2015). Evaluation of pesticide residues in fruits and vegetables from the region of south-eastern Poland. Food Control, 48, 137142. 
World Health Organization. (2017). Pesticide residues in food-2016: toxicological evaluations. Joint Meeting of the FAO Panel of Experts on Pesticide Residues in Food and the Environment and the WHO Core Assessment Group on Pesticide Residues, Geneva, Switzerland, 9-13 May 2016.
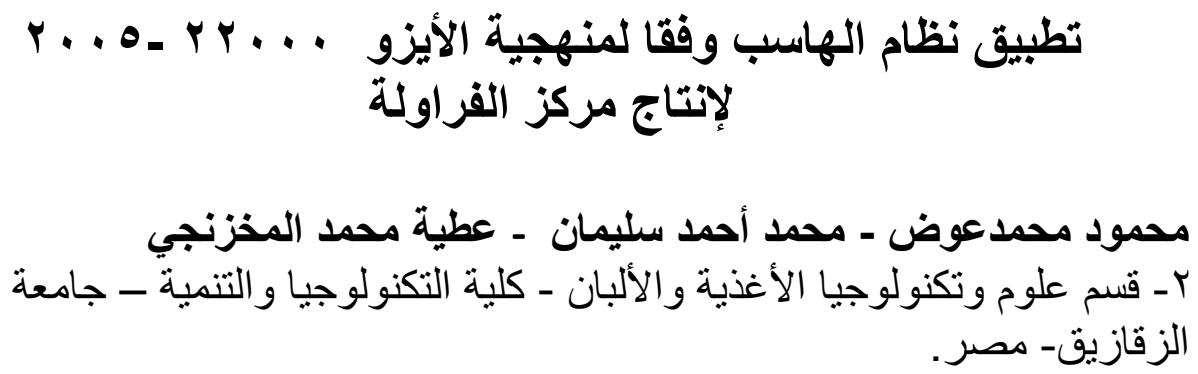

كان الغرض من هذه الدراسة هو تقديم منهجية للقيام بتقييمات المخاطر من أجل

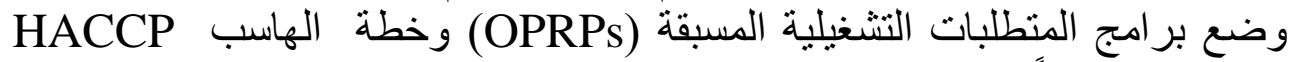
وفقاً لمنهجية Plan

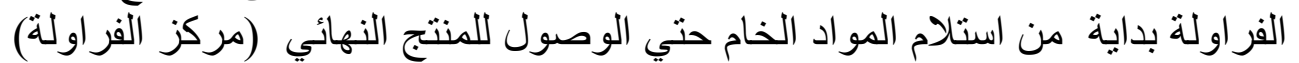

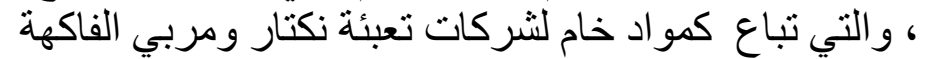

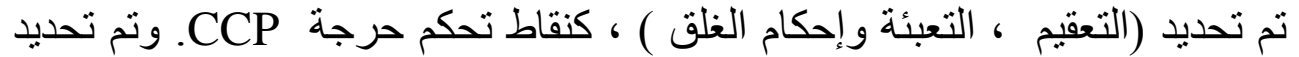

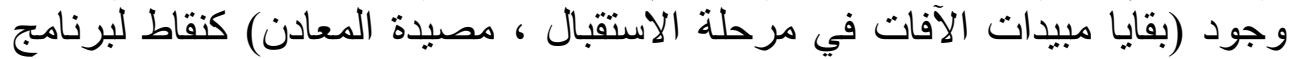

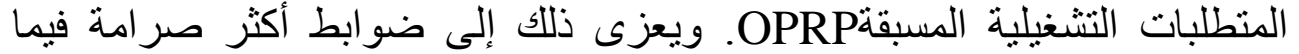
يتعلق بممارسات التصنيع الجيد (GMP) و ممارسات المعامل الجيدة (GLPs)

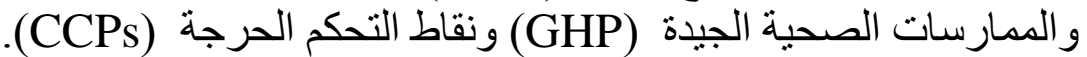

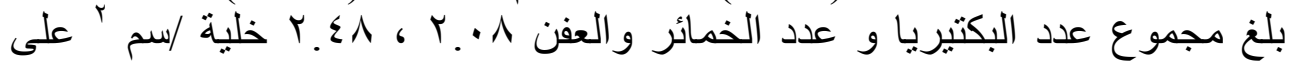

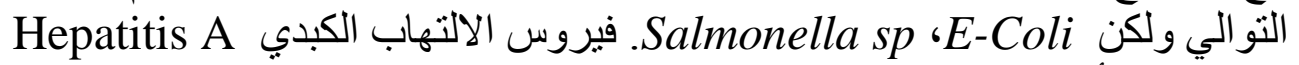

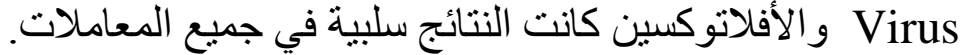

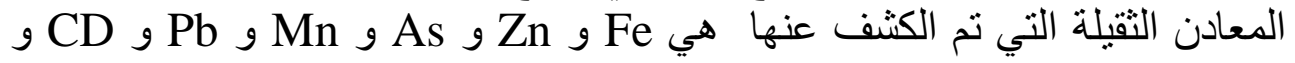

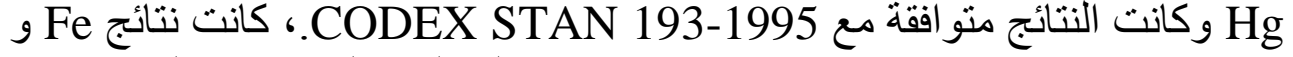

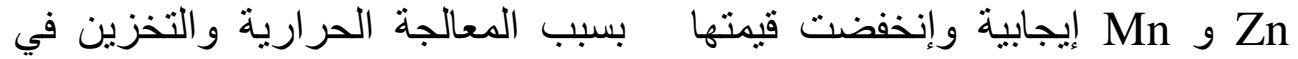


درجات حرارة منخفضة ب م م ، أما بالنسبة لـ Hg d d d , P b كانت النتائج سلبية

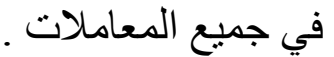

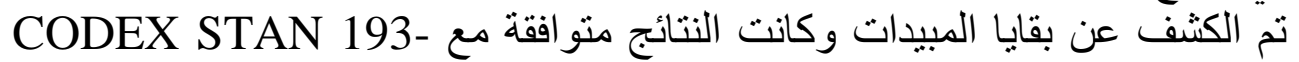
1995. و إنخفضت قيمتها بسبب المعالجة الحرارية والعمليات التصنية التيعية و التخزين

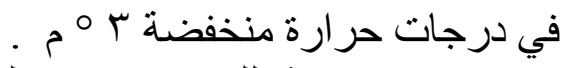

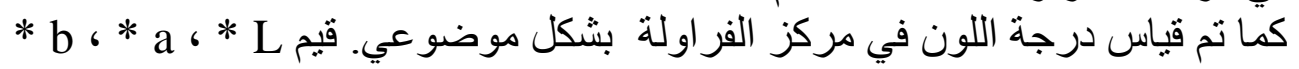

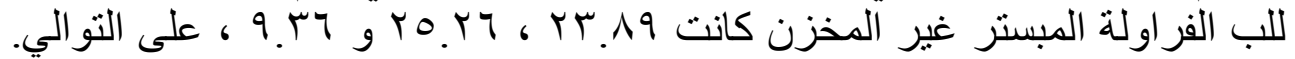

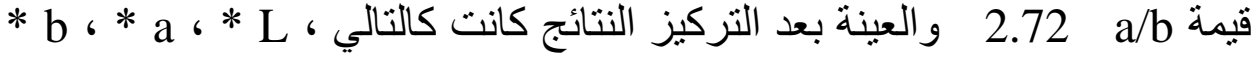

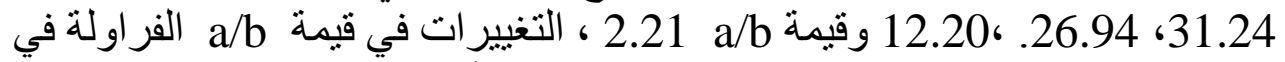

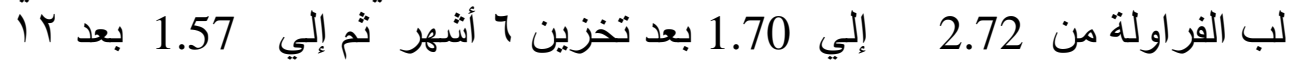

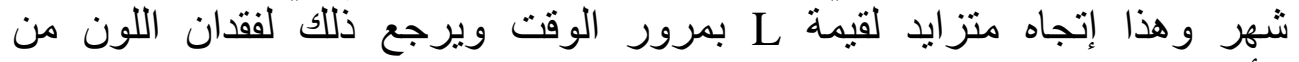

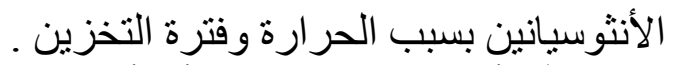

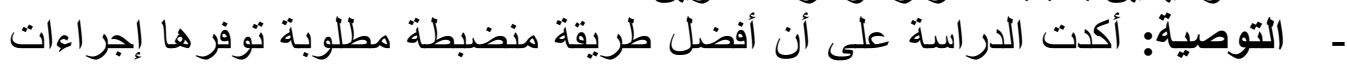

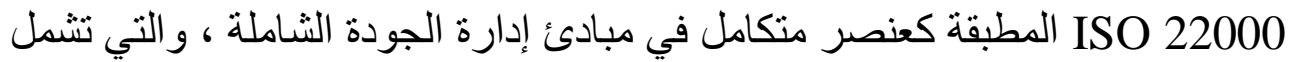
ISO و GLP و GHP و GMP و GHACCP)

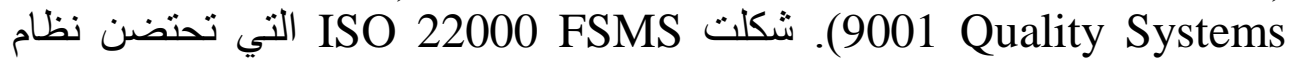
ومر اقبة الوثائق إطارًا مهمًا يمكن من خلاله توصيل منطلبات الجودة بفعالية وبطريقة يمكن إثباتها ومر اجعتها. 